\title{
THE METABOLISM OF CITRATE-C ${ }^{14}$ IN NORMAL AND IN FLUOROINHIBITOR-POISONED RATS *
}

\author{
By EDWIN E. GORDON \\ (From the Department of Medicine, Albert Einstein College of Medicine, Yeshiva University, \\ and the Bronx Municipal Hospital Center, New York, N. Y.)
}

(Submitted for publication March 1, 1961 ; accepted May 29, 1961)

A cyclical exchange of citrate has been shown to exist in the intact organism, with the blood plasma serving as the transporting medium. In vivo studies have indicated a considerable uptake of citrate by the liver (1) and kidney (2), and a release of citrate into the blood by the peripheral tissues $(1,3)$ and intestine $(4,5)$. Interest in the blood citrate flux has centered primarily around the importance of this intermediate in carbohydrate metabolism, in its relationship to calcium mobilization and deposition in bone (6), and in its role as a chelating agent for calcium in the urine $(7,8)$.

The studies reported here have been concerned with an attempt to elucidate the metabolic fate of the blood citrate in rats with the aid of radioactive citrate. The data, obtained by following the pattern of respiratory $\mathrm{C}^{14} \mathrm{O}_{2}$ and the urinary excretion of radioactive carbon after the intravenous administration of sodium citrate-1,5- $\mathrm{C}^{14}$, indicated a rapid turnover of the blood citrate. Three hours after injection of the labeled citrate, approximately 90 per cent of the radioactivity was recovered in the respiratory $\mathrm{CO}_{2}$ and in the urinary citrate. Evidence for the utilization of blood citrate as a precursor of tissue components was provided by assaying the $\mathrm{C}^{14}$ content of protein and lipid of kidneys and liver after intravenous citrate- $\mathrm{C}^{14}$ administration.

In an effort to define further the metabolic fate of the blood citrate, inhibitors of citrate oxidation were administered prior to citrate- $\mathrm{C}^{14}$ administration. Peters (9) has shown that fluoroacetate inhibits the enzyme, aconitase, by virtue of its conversion to fluorocitrate. As a consequence of aconitase inhibition, the metabolism of citrate to

* This work was supported by Research Grant A-2598 from the National Institutes of Health. Presented in part at the April, 1961 meeting of the Federation of American Societies for Experimental Biology, Atlantic City, N. J. isocitrate in the Krebs tricarboxylic acid cycle is blocked. In our experiments both fluoroacetate and fluorocitrate influenced the fate of the administered citrate- $\mathrm{C}^{14}$. In the intact animal the effects of each of the inhibitors were strikingly different: fluroacetate resulted in a decreased, and fluorocitrate resulted in an increased urinary excretion of citrate- $\mathrm{C}^{14}$. Tissue slice experiments confirmed this difference in the action of the inhibitors. In contrast to the postulate of Peters, the in vitro data are consistent with the view that fluoroacetate is also an inhibitor of the condensing enzyme.

\section{MATERIALS AND METHODS}

Fed, female Sprague-Dawley rats, weighing between 185 and $235 \mathrm{~g}$, were used. Citric acid-1,5- $\mathrm{C}^{14}$ was obtained from Tracerlab, Inc., and sodium acetate-1- $\mathrm{C}^{14}$ from Volk Radiochemical Co. Sodium fluoroacetate ${ }^{1}$ was purchased from Bios Laboratories, Inc. Barium fluorocitrate, synthesized by the method of Rivett (10), was obtained from the Sonbert Chemical Co., Brooklyn, N. Y.; this preparation contained less than 1 per cent barium citrate by specific analysis. Before use, the barium salt was dissolved in dilute $\mathrm{HCl}$, the barium was precipitated with saturated sodium sulfate and the supernatant fluid was neutralized with dilute $\mathrm{NaOH}$. Solutions of the fluoroinhibitors were freshly prepared prior to use.

In the in vivo experiments, sodium citrate- $1,5-\mathrm{C}^{14}$ in isotonic saline was given intravenously in a volume of 0.3 ml. Collection of respiratory $\mathrm{CO}_{2}$ was accomplished by drawing $\mathrm{CO}_{2}$-free air through a glass metabolism jar containing the rat, and the respiratory $\mathrm{CO}_{2}$ was trapped in $\mathrm{NaOH}$. Barium carbonate precipitates were prepared from aliquots of the $\mathrm{NaOH}$ solutions. After the $\mathrm{BaCO}_{3}$ was washed with water and then alcohol, it was plated and counted in a Nuclear-Chicago gas-flow counter with a Micromil window. Urine collections were made up to standard volume, and aliquots were taken for direct plating and for conversion of the carboxyl groups of the urinary citrate to $\mathrm{CO}_{2}$ with ceric sulfate (11); the $\mathrm{CO}_{2}$

1 Elementary analysis: $\mathrm{C}_{2} \mathrm{H}_{2} \mathrm{O}_{2} \mathrm{~F} \mathrm{Na}(100.0)$; calculated, C 24.0, H 2.0, F 19.0; found, C 24.3, H 2.1, F 18.2; performed by the Schwarzkopf Microanalytical I.ah., Woodside, N. Y. 
was collected in $\mathrm{NaOH}$ and subsequently converted to $\mathrm{BaCO}_{3}$ for radioactive assay as stated above. Because of the lack of absolute specificity of the ceric sulfate method for measurement of citrate in the presence of other intermediates, another method was used to verify the specific activity of the urinary citrate. Interfering inorganic salts of urine were removed by passage through a Dowex-2 column (12). The column eluate was taken to dryness, made up to volume with water and an aliquot subjected to ascending chromatography on Whatman no. 4 paper in a $n$-butanol: acetic acid: water system $(120: 30: 50)$. The citric acid was located by means of an indicator spray (13), the spot was eluted and aliquots were taken for determination of citrate and for conversion of the carboxyl groups to $\mathrm{BaCO}_{3}$ as described above. The results of this technique for measuring the specific activity of the citrate were in good agreement with those obtained by direct treatment of urine with ceric sulfate.

Three hours after administration of the radioactive citrate, the rats were sacrificed by cervical fracture, and the kidneys and liver were removed and weighed. Portions of each of the organs were taken for isolation of lipid (14) and protein (15). The lipid was plated on planchets containing a circle of lens paper, and the protein was counted as a powder. All radioactive samples were corrected for self-absorption and the values converted to infinite thickness.

In the in vivo fluoroinhibitor experiments, fluoroacetate or fluorocitrate was injected intraperitoneally, in a volume not exceeding $0.4 \mathrm{ml}, 30$ minutes prior to citrate$\mathrm{C}^{14}$ administration. The respiratory $\mathrm{CO}_{2}$ and urine were collected, plated and counted as described above. After the rats were sacrificed, weighed portions of kidney, liver, heart, and spleen were homogenized in ice-cold 5 per cent trichloroacetic acid. After centrifugation the citrate concentration of the supernatant fluid was estimated by the Eliott modification of the Natelson, Pincus and Lugovoy method (16).

In vitro studies of liver and kidney slices, prepared with a Stadie-Riggs microtome, were carried out in 25- $\mathrm{ml}$ Erlenmeyer flasks with a sealed-in center well containing filter paper saturated with $0.2 \mathrm{ml}$ of 5 per cent $\mathrm{NaOH}$. Slices of liver (approximately $400 \mathrm{mg}$ per vessel) and kidney (approximately $150 \mathrm{mg}$ per vessel) were incubated in $3 \mathrm{ml}$ of Krebs-Ringer phosphate buffer containing 200 $\mathrm{mg}$ per $100 \mathrm{ml}$ glucose, $\mathrm{pH} 7.4$. After a 15 -minute equilibration period at $37^{\circ} \mathrm{C}$ in a Dubnoff metabolic shaker under 100 per cent $\mathrm{O}_{2}$, a trace dose of citrate-1,5-C $\mathrm{C}^{14}$ or acetate$1-\mathrm{C}^{14}$ was added to the flasks. The closed flasks were then incubated for 60 minutes and the $\mathrm{C}^{14} \mathrm{O}_{2}$ produced was trapped in the $\mathrm{NaOH}$ of the center well. Fluoroacetate was present in a concentration of $2.5 \times 10^{-4} \mathrm{M}$ and fluorocitrate in a concentration of $5 \times 10^{-4} \mathrm{M}$. At the end of the incubation period, the center well $\mathrm{NaOH}$ was collected, carrier $\mathrm{NaHCO}_{3}$ was added, and the samples were converted to $\mathrm{BaCO}_{3}$ for plating and counting. The tissue was homogenized in the incubating medium and flask washings, and the protein was precipitated with ill equal volume of 10 per cent trichloroacetic acid.
Fractionation of liver and kidney tissues to determine the intracellular distribution of citrate was carried out by a modification of the method of Schneider (17). A 10 per cent $(\mathrm{wt} / \mathrm{vol})$ homogenate of the tissue was prepared in $0.25 \mathrm{M}$ sucrose with a motor-driven Teflon pestle or with a Dounce homogenizer at $0^{\circ} \mathrm{C}$. A portion of the whole homogenate was stored at $0^{\circ}$ until the end of the separation procedure. Further fractionation of the whole homogenate was accomplished by centrifuging at $700 \mathrm{G}$ for 10 minutes at $5^{\circ} \mathrm{C}$. The supernatant solution was removed and the sediment was resuspended in $0.25 \mathrm{M}$ sucrose, homogenized, and centrifuged at $700 \mathrm{G}$ for 10 minutes. This supernatant was combined with the supernatant from the first centrifugation and the sediment was resuspended in water and homogenized; this nuclear fraction was stored at $0^{\circ}$ until the end of the fractionation procedure. The combined supernatants were then spun at $5^{\circ}$ for 10 minutes at $5,000 \mathrm{G}$ to sediment the mitochondria. The supernatant and the fluffy layer containing microsomes and soluble cytoplasm were removed, and this fraction is referred to as the extramitochondrial fraction. The sediment, representing the mitochondrial fraction, was resuspended and homogenized in distilled water. Appropriate aliquots of each of the fractions were added to equal volumes of 10 per cent trichloroacetic acid and the protein was removed by centrifugation. Citrate determinations in the presence of sucrose were carried out by a modification of the pentabromacetone procedure (18).

\section{RESULTS}

The fate of intravenously administered citrate$C^{14}$ in the intact rat. Initially, the rates of conversion of $4 \mu \mathrm{g}$ of citrate-C $\mathrm{C}^{14}\left(1.1 \times 10^{5} \mathrm{cpm}\right)$ and $125 \mu \mathrm{g}$ of citrate- $\mathrm{C}^{14}\left(5.6 \times 10^{6} \mathrm{cpm}\right)$ to respiratory $\mathrm{CO}_{2}$ and urinary citrate were compared in order to determine whether the larger quantity of citrate could be administered without significantly altering the physiological state (Table I). The rate of conversion of the radioactive carbon of citrate- $\mathrm{C}^{14}$ to respiratory $\mathrm{CO}_{2}$ and the percentage of the administered label in the urinary citrate were independent of the amount of citrate- $\mathrm{C}^{14}$ ad-

TABLE I

The percentage of counts after 3 hours in the respiratory $\mathrm{CO}_{2}$ and urinary citrate as a function of the quantity of citrate- $C^{14}$ injected *

\begin{tabular}{ccc}
\hline Citrate injected & Respiratory $\mathrm{CO}_{2}$ & Urinary citrate \\
\hline$\mu g$ & & \\
4 & $54.4 \pm 4.9[5]$ & $26.8 \pm 3.0[6]$ \\
125 & $55.5 \pm 1.0[5]$ & $34.4 \pm 2.4[5]$
\end{tabular}

* The number of rats in each series is indicated in brackets; the values are the mean \pm standard error. 

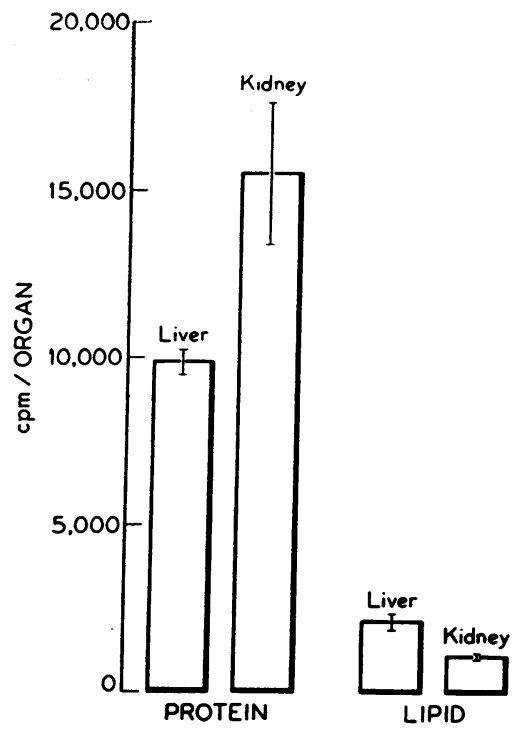

Fig. 1. The incorporation of $\mathrm{C}^{14}$ into total Lipid AND PROTEIN OF THE RAT KIDNEY AND LIVER 3 HOURS AFTER ADMINISTRATION OF CITRATE- $C^{14}$. The values are the means of 4 rats \pm standard error.

ministered (a $t$ test of differences for each of the parameters revealed $p>0.05$ ). Eighty to 90 per cent of the administered radioactivity was recovered in the 3-hour period. Since these results indicated that $125 \mu \mathrm{g}$ of citrate could be administered intravenously without gross distortion of the metabolic fate of the blood citrate, this quantity was used in all subsequent in vivo experiments.

After 3 hours, approximately 1 per cent of the radioactive carbon of citrate- $\mathrm{C}^{\mathbf{1 4}}$ was incorporated into the protein and lipid moieties of kidney and liver. The incorporation of the $\mathrm{C}^{14}$ into the protein of these organs was far greater than that incorporated into the lipid (Figure 1). The $\mathrm{C}^{14}$ content of kidney protein was not significantly different from that of liver protein $(p>0.05)$, but the $\mathrm{C}^{14}$ content of kidney lipid was less than

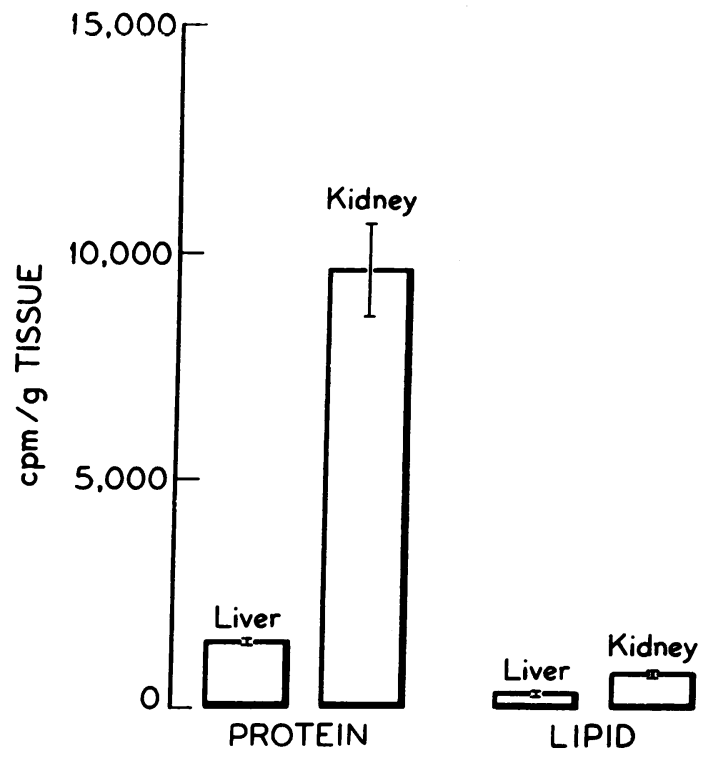

Fig. 2. ThE INCORPORATION OF $\mathrm{C}^{14}$ INTO LIPID AND PROTEIN OF RAT LIVER AND KIDNEY 3 HOURS AFTER ADMINISTRATION OF CITRATE- ${ }^{14}$, EXPRESSED AS COUNTS PER MINUTE PER GRAM TISSUE. The values are the means of 4 rats \pm standard error.

that of liver lipid $(p<0.025)$. The data also indicate (Figure 2) that incorporation of the radioactive carbon of citrate- $\mathrm{C}^{14}$ into kidney tissue components was far greater than that incorporated into liver tissue components when expressed on a gram-weight basis $(p<0.001$ for lipid, $\mathrm{p}<0.001$ for protein).

Effect of fluoroacetate and fluorocitrate in the intact rat. In the intact animal, fluorocitrate differed from fluoroacetate with respect to its effect on the metabolism of citrate. The effectiveness of these substances as inhibitors of metabolism in vivo is reflected in the accumulation of tissue citrate (Table II) ; 3.5 hours after the intraperitoneal administration of fluoroacetate at a level

TABLE II

Tissue citrate *

\begin{tabular}{|c|c|c|c|c|}
\hline Fluoroinhibitor & None [4] & $\begin{array}{l}\text { Fluoroacetate [4] } \\
\qquad(2.5 \mathrm{mg} / \mathrm{kg})\end{array}$ & $\begin{array}{l}\text { Fluorocitrate } \\
\quad(20 \mathrm{mg} / \mathrm{kg})\end{array}$ & $\begin{array}{c}\text { Fluorocitrate } \\
(40 \mathrm{mg} / \mathrm{kg})\end{array}$ \\
\hline $\begin{array}{l}\text { Heart } \\
\text { Kidney } \\
\text { Spleen } \\
\text { Liver }\end{array}$ & $\begin{array}{l}15.6 \pm 6.2 \\
32.2 \pm 8.1 \\
33.2 \pm 5.6 \\
23.1 \pm 6.5\end{array}$ & $\begin{array}{r}504 \pm 83 \\
1,118 \pm 65 \\
1,011 \pm 46 \\
336 \pm 50\end{array}$ & $\begin{array}{l}43.2 \pm 4.2 \\
88.4 \pm 6.1 \\
84.1 \pm 15.8 \\
64.8 \pm 10.5\end{array}$ & $\begin{array}{l}50.8 \pm 12 \\
175 \pm 24 \\
193 \pm 11 \\
110 \pm 8\end{array}$ \\
\hline
\end{tabular}

* Accumulation of citrate (in $\mu \mathrm{g} / \mathrm{g}$ wet weight tissue) in female rat tissues 3.5 hours after the intraperitoneal administration of fluoroinhibitor. The values are the mean \pm standard error. The number of animals in each group is indicated in brackets. 


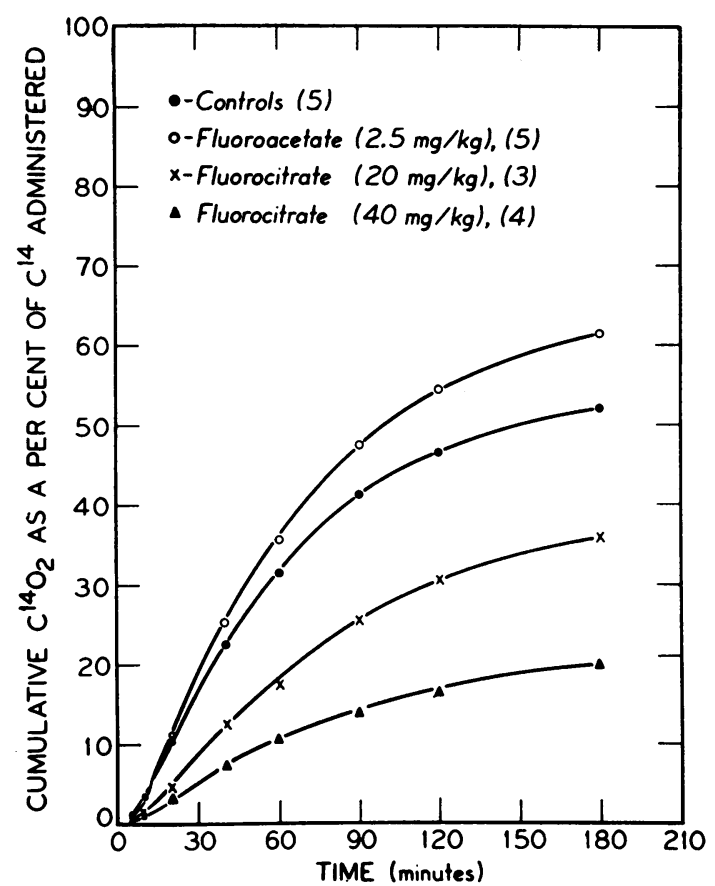

Fig. 3. The Conversion of intravenously aDMINISTERED CITRATE-1,5- $\mathrm{C}^{14}$ TO $\mathrm{C}^{14} \mathrm{O}_{2}$ IN NORMAL RATS AND IN RATS PRETREATED WITH FLUOROINHIBITORS. The fluoroinhibitors were injected intraperitoneally $30 \mathrm{~min}-$ utes prior to citrate- $\mathrm{C}^{\mathbf{1 4}}$ administration. The values are the means for the number of animals (indicated in parentheses).

of $2.5 \mathrm{mg}$ per $\mathrm{kg}$ ( $25 \mu$ moles per $\mathrm{kg}$ ) or fluorocitrate at a level of 20 and $40 \mathrm{mg}$ per $\mathrm{kg}$ ( 50 and $100 \mu$ moles per $\mathrm{kg}$ ), the concentration of citrate in the tissues was increased over the control, in agreement with the data of Gal, Peters and Wakelin (19). There was approximately a 30 -fold increase in heart, kidney and spleen citrate and a 15 -fold increase in liver citrate in the fluoroacetate-treated animals; fluorocitrate increased the tissue citrate concentration three- to sixfold. Despite the markedly greater inhibition of citrate metabolism by fluoroacetate when tissue citrate concentrations were used as a guide, the conversion of intravenously administered $\mathrm{C}^{14}$-labeled citrate to respiratory $\mathrm{C}^{14} \mathrm{O}_{2}$ was greater $(\mathrm{p}<$ $0.01)$ in the fluoroacetate-treated than in the control animals (Figure 3). On the other hand, fluorocitrate administration resulted in a depression ( $p<0.001$ at 20 and $40 \mathrm{mg}$ per $\mathrm{kg}$ ) of respiratory $\mathrm{C}^{14} \mathrm{O}_{2}$ from labeled citrate.

The effect of these fluoroinhibitors on endogenous citrate metabolism and the fate of adminis- tered citrate- $\mathrm{C}^{14}$ was further studied by examining the urine and blood of these animals (Table III). After 3 hours, approximately 35 per cent of the administered $\mathrm{C}^{14}$ was found in the urine, whereas 50 per cent of the radioactivity was found in the urine of fluorocitrate-poisoned animals and 15 per cent in the urine of the fluoroacetate-poisoned animals. Essentially all of the radioactivity of the urine after citrate-C $\mathrm{C}^{14}$ administration was present in the carboxyl groups of the urinary citrate. Fluoroacetate treatment did not affect the quantity of citrate excreted in the urine, but fluorocitrate administration resulted in a four- to fivefold increase in urinary citrate excretion. Blood citrate levels were increased two to three times over normal when the animals received either fluoroacetate or fluorocitrate. These findings indicated that the difference in the pattern of respiratory $\mathrm{C}^{14} \mathrm{O}_{2}$ after citrate- $\mathrm{C}^{14}$ administration in the fluoroinhibitor-treated rats was the result of alterations in the renal clearance of the labeled citrate as well as inhibition of citrate oxidation.

In vitro activity of fuoroinhibitors on citrate and acetate metabolism. In view of the discrepancy between fluoroacetate and fluorocitrate action on citrate metabolism in the intact animal, in vitro studies were carried out with slices of rat liver and kidney (Table IV). It has been suggested by Gal and co-workers (19) that only two of the four isomers of chemically synthesized fluorocitrate are biologically active; thus the effective molar concentrations of the two fluoroinhibitor compounds studied in vitro were the same, $2.5 \times 10^{-4} \mathrm{M}$. At this concentration there was an accumulation of citrate in the incubation vessels when either of the fluoroinhibitors was

TABLE III

The blood and urine citrate concentration in normal and fuoroinhibitor-treated rats *

\begin{tabular}{lrrr}
\hline & Normal & $\begin{array}{c}\text { Fluoro- } \\
\text { acetate } \\
(2.5 \mathrm{mg} / \mathrm{kg})\end{array}$ & $\begin{array}{c}\text { Fluoro- } \\
\text { citrate } \\
(20 \mathrm{mg} / \mathrm{kg})\end{array}$ \\
\hline Blood citrate $(\mu \mathrm{g} / \mathrm{ml})$ & $33.2 \pm 3.4$ & $91.6 \pm 6.3$ & $66.0 \pm 3.6$ \\
$\begin{array}{l}\text { Urine citrate }(\mathrm{mg} / 3 \mathrm{hrs}) \\
\begin{array}{l}\text { \% Counts injected } \\
\text { Urine } \\
\text { Urinary citrate }\end{array}\end{array}$ & $\mathbf{8 . 1 \pm 0 . 7}$ & $\mathbf{6 . 1} \pm 1.3$ & $\mathbf{3 5 . 4} \pm 1.4$ \\
\hline
\end{tabular}

* Citrate-1,5-C14 was injected intravenously 30 minutes after the intraperitoneal administration of the fluoroinhibitor, and the urine was then collected for 3 hours. Five rats were used in each series and the values represent the mean \pm standard error. 
TABLE IV

The cffecl of fluoroacelale and fuorocitrate on in vitro metabolism of liver and kidney*

\begin{tabular}{|c|c|c|c|c|}
\hline & \multicolumn{2}{|c|}{ Citrate-1,5-C14 } & \multicolumn{2}{|c|}{ Acetate-1-C14 } \\
\hline & $\begin{array}{c}\text { Citrate } \\
\text { produced } \\
(\mu g / g \text { wet } w t)\end{array}$ & $\begin{array}{c}\mathrm{C}^{14} \mathrm{O}_{2} \\
\text { produced } \\
(c p m / m g \text { wet } w t)\end{array}$ & $\begin{array}{c}\text { Citrate } \\
\text { produced } \\
(\mu g / g \text { wet } w t)\end{array}$ & $\begin{array}{c}\mathrm{C}_{14 \mathrm{O}_{2}} \\
\text { produced } \\
(\mathrm{cpm} / \mathrm{mg} \text { wet wt })\end{array}$ \\
\hline \multicolumn{5}{|l|}{ Liver } \\
\hline $\begin{array}{l}\text { Control } \\
\text { Fluoroacetate } \\
\text { Fluorocitrate }\end{array}$ & $\begin{array}{r}26 \pm 2 \\
122 \pm 11 \\
438 \pm 12\end{array}$ & $\begin{array}{l}75 \pm 4 \\
53 \pm 2 \\
7 \pm 0.5\end{array}$ & $\begin{array}{r}2 \pm 3 \\
93 \pm 15 \\
423 \pm 28\end{array}$ & $\begin{array}{l}139 \pm 8 \\
66 \pm 4 \\
18 \pm 0.7\end{array}$ \\
\hline \multicolumn{5}{|l|}{ Kidney } \\
\hline $\begin{array}{l}\text { Control } \\
\text { Fluoroacetate } \\
\text { Fluorocitrate }\end{array}$ & $\begin{array}{r}16 \pm 10 \\
567 \pm 30 \\
938 \pm 50\end{array}$ & $\begin{array}{r}459 \pm 25 \\
393 \pm 30 \\
78 \pm 28\end{array}$ & $\begin{array}{r}13 \pm 12 \\
532 \pm 24 \\
867 \pm 45\end{array}$ & $\begin{array}{l}796 \pm 25 \\
569 \pm 20 \\
638 \pm 25\end{array}$ \\
\hline
\end{tabular}

* The values represent the mean \pm standard error of 8 observations.

present; fluorocitrate was about twice as effective as fluoroacetate in this regard for kidney slices and about four times as effective with liver slices. It should be noted that the conversion of citrate- $\mathrm{C}^{14}$ and acetate- $\mathrm{C}^{14}$ to $\mathrm{C}^{14} \mathrm{O}_{2}$ by kidney slices was approximately six times greater than with liver slices in the absence of inhibitors. Similarly, the uptake of unlabeled citrate, present in the incubation medium at a concentration of 5 mmoles per $\mathrm{L}$ by kidney slices was about six to seven times that found with liver slices (20). Differences in tissue responsiveness to these inhibitors are pointed up by the fact that fluorocitrate had a more striking effect on liver tissue than did fluoracetate in regard to the conversion of either citrate- $\mathrm{C}^{14}$ or acetate- $\mathrm{C}^{14}$ to $\mathrm{C}^{14} \mathrm{O}_{2}$. In contrast,

TABLE $V$

Distribution of citrate in the subcellular fractions of kidney and liver prepared from rats pretreated with fluoroinhibitors *

\begin{tabular}{lcccc}
\hline & \multicolumn{2}{c}{ Fluoroacetate } & \multicolumn{2}{c}{ Fluorocitrate } \\
\hline & $\begin{array}{l}\mu g \text { cit./ } \\
\text { g tissue }\end{array}$ & $\begin{array}{c}\text { \% tissue } \\
\text { cit. }\end{array}$ & $\begin{array}{c}\mu g \text { cit./ } \\
\text { g tissue }\end{array}$ & $\begin{array}{c}\% \text { tissue } \\
\text { cit. }\end{array}$ \\
Liver & & & & \\
$\quad$ Whole homogenate & 326 & 100 & 526 & 100 \\
Nuclear fraction & 48.0 & 14.7 & 53.7 & 10.2 \\
$\begin{array}{l}\text { Mitochondrial fraction } \\
\text { Extramitochondrial }\end{array}$ & 202 & 62.0 & 338 & 64.3 \\
$\quad$ fraction & 74 & 22.7 & 196 & 22.7 \\
Kidney & & & & \\
$\begin{array}{l}\text { Whole homogenate } \\
\text { Nuclear fraction }\end{array}$ & 6.30 & 100 & 597 & 100 \\
$\begin{array}{l}\text { Mitochondrial fraction } \\
\text { Extramitochondrial }\end{array}$ & 187 & 9.1 & 49.7 & 8.3 \\
$\quad$ fraction & 320 & 28.6 & 134 & 22.5 \\
& & 50.8 & 365 & 61.1 \\
\hline
\end{tabular}

* The fluoroacetate $(2.5 \mathrm{mg} / \mathrm{kg})$ and fluorocitrate $(20 \mathrm{mg} / \mathrm{kg})$ were administered intraperitoneally and the animals were sacrificed 2 hours later. the conversion of acetate- $\mathrm{C}^{14}$ to $\mathrm{C}^{14} \mathrm{O}_{2}$ by kidney tissue was inhibited to the same extent when either fluoroacetate or fluorocitrate was present. Citrate$\mathrm{C}^{14}$ conversion to $\mathrm{C}^{14} \mathrm{O}_{2}$ by kidney was inhibited to a much greater extent by fluorocitrate than by fluoroacetate. With liver slices, fluoroacetate proved to be a more effective inhibitor of acetate metabolism than of citrate metabolism.

Intracellular distribution of citrate after fuoroinhibitor administration. Additional information concerning citrate metabolism was obtained by studying citrate accumulation in subcellular components of kidney and liver tissue after administration of each of the fluoroinhibitors to rats (Table V). In control animals, the preponderance of tissue citrate was localized in the mitochondrial fraction of kidney and liver. After administration of fluoroacetate to rats, approximately 60 per cent of the liver citrate was found in the mitochondrial fraction, in confirmation of the data of Schneider, Striebich and Hogeboom (18). In most instances the remainder of the tissue citrate could be accounted for in the nuclear fraction and in the fraction not sedimented by centrifuging at 5,000 $\mathrm{G}$ for 10 minutes. Essentially the same distribution of citrate in liver tissue was found in the fluorocitrate-treated animal. In contrast, about one-half to two-thirds of kidney citrate was recovered in the fraction not sedimenting at $5,000 \mathrm{G}$ for 10 minutes when either fluoroacetate or fluorocitrate was administered to the animal; the balance of the tissue citrate was found in the mitochondrial and nuclear fractions. Tissue fractionation with $0.88 \mathrm{M}$ sucrose, isotonic saline, 7.3 
per cent polyvinylpyrrolidone- $0.25 \mathrm{M}$ sucrose (21) resulted in essentially the same distribution of tissue citrate after fluoroinhibitor administration as $\operatorname{did} 0.25 \mathrm{M}$ sucrose.

\section{DISCUSSION}

These investigations revealed that the blood citrate is metabolized at a rapid rate, as indicated by following the fate of intravenously injected radioactive citrate. By 3 hours, 55 per cent of the label was found in the respiratory $\mathrm{CO}_{2}$; of the total radioactivity administered, 35 per cent was recovered in the urinary citrate. Thus, about 85 per cent of the citrate- $\mathrm{C}^{14}$ that remained in the animal was metabolized to $\mathrm{C}^{14} \mathrm{O}_{2}$ in 3 hours. This rate approaches that seen after administration of acetate-1-C $\mathrm{C}^{14}$ to rats (22). The rapid turnover of the blood citrate dictates that there is an equally rapid outflux from the tissues. A similar respiratory $\mathrm{C}^{14} \mathrm{O}_{2}$ pattern was obtained by Lussier (23) after the intraperitoneal injection of $2 \mathrm{mg}$ radioactive citric acid; only 10 per cent of the administered label was recovered in the urine in 8 hours, in contrast to the findings reported here. Since urinary citrate- $\mathrm{C}^{14}$ excretion is markedly depressed when $1.5 \mathrm{mEq}$ of $\mathrm{HCl}$ is introduced into the stomach prior to injection of citrate- $\mathrm{C}^{14}$ (20), it seems likely that the low levels obtained in the earlier experiments were due to the administration of the radioactive compound as the free acid.

Evidence for the utilization of the blood citrate as a precursor of tissue components is provided by the finding that approximately 1 per cent of administered $\mathrm{C}^{14}$ as citrate- $\mathrm{C}^{14}$ was incorporated into lipid and protein of the kidneys and liver (Figure 1). Kidney was much more active in this respect than liver when the data are calculated as counts per minute incorporated per gram of tissue (Figure 2). It is likely that an appreciable portion of the injected radioactivity that remains unaccounted for was taken up by bone and later released or metabolized (23).

Peters (9) has demonstrated that fluoroacetate is converted to fluorocitrate by biological systems, with consequent inhibition of the enzyme, aconitase. Other studies (19), however, indicated that these two compounds did not result in equivalent inhibitory activities when administered to rats. It was shown that fluorocitrate, but not fluoro- acetate, resulted in an appreciable accumulation of citrate in the livers of male rats, in contrast to the findings in female rats (Table II). Further, citrate accumulation in the heart was considerably greater after fluoroacetate than fluorocitrate administration. The present study of the effect of fluoroacetate and fluorocitrate on citrate metabolism provides additional evidence for the divergent action of these two inhibitors in vivo and in tissue slices.

In the intact animal, conversion of citrate- $\mathrm{C}^{14}$ to respiratory $\mathrm{C}^{14} \mathrm{O}_{2}$ was enhanced by pretreatment with fluoroacetate despite inhibition of citrate metabolism, as evidenced by accumulation of citrate in the tissues. In animals pretreated with fluorocitrate, conversion of citrate- $\mathrm{C}^{14}$ to respiratory $\mathrm{C}^{14} \mathrm{O}_{2}$ was depressed; in this case the amount of citrate that had accumulated within the tissues was far less than that observed in the fluoroacetate-treated rats. These seemingly paradoxical findings were partially resolved upon analysis of the urinary excretion of the labeled citrate. In the one instance, fluoroacetate markedly inhibited the urinary excretion of the radioactive carbon, while fluorocitrate treatment resulted in an increased urinary excretion of radioactive carbon. Because of this, more radioactive citrate was available for oxidation to respiratory $\mathrm{C}^{14} \mathrm{O}_{2}$ in the fluoroacetate-treated rat than in the normal and fluorocitrate-treated rat. In the fluoroacetatepoisoned rat one might expect that the administered radioactive citrate would be diluted to a large extent by the increased concentration of citrate in the tissues, with a consequent decreased rate of oxidation of the citrate- $\mathrm{C}^{14}$ to $\mathrm{C}^{14} \mathrm{O}_{2}$. Since this was not the case, the existence of more than one pool of citrate within the organism is suggested.

Another difference in the action of these fluoroinhibitors was noted; fluorocitrate, unlike fluoroacetate, caused striking increases in total urinary citrate excretion. Since the blood citrate levels were markedly elevated in both the fluoroacetateand fluorocitrate-treated rats, the data indicate that the renal tubular mechanism for handling citrate is affected diversely by each of the fluoroinhibitors that was tested.

Further confirmation of the difference in tissue responsiveness to fluorocitrate and fluoroacetate was obtained from in vitro tissue-slice ex- 
periments. The data indicate that fluoroacetate served as a more effective inhibitor of acetate oxidation than of citrate oxidation in both liver and kidney slices. This observation is in agreement with the finding of decreased acetate utilization by slices of heart, kidney and liver when fluoroacetate was present in the incubation medium (24). In other experiments Kalnitsky (25) demonstrated that the presence of fluoroacetate at a concentration of $0.001 \mathrm{M}$ completely inhibited acetate utilization and only slightly inhibited citrate utilization by rabbit kidney cortex homogenates. A possible explanation of these findings is provided by the fact that fluoroacetyl coenzyme A behaves as a strong competitive inhibitor of the condensing enzyme (26).

Schneider and co-workers (18) demonstrated that the accumulation of liver citrate after fluoroacetate administration to the animal could be found primarily in the mitochondrial fraction. Other experiments have shown that aconitase, the enzyme competitively inhibited by fluorocitrate, exists in two forms, each displaying characteristic $\mathrm{pH}$ optima $(27,28)$. These observations prompted an investigation of the effect of fluoroacetate and fluorocitrate on the intracellular distribution of citrate in liver and kidney tissue. The present studies confirmed the localization of citrate in liver mitochondria after fluoroacetate poisoning and, in addition, showed that fluorocitrate resulted in essentially the same intracellular distribution of citrate. Analysis of kidney tissue of animals treated with fluoroacetate or fluorocitrate revealed a different distribution of citrate in the subcellular fractions from that of liver. Pretreatment with fluoroacetate or fluorocitrate resulted in essentially the same distribution of citrate within the subcellular fractions of kidney tissue. No evidence is available to provide an explanation for the difference between liver and kidney tissue in the subcellular localization of citrate after fluoroinhibitor treatment.

\section{SUMMARY}

The turnover of the blood citrate is extremely rapid as measured by the conversion of intravenously administered citrate- $\mathrm{C}^{14}$ to respiratory $\mathrm{C}^{14} \mathrm{O}_{2}$. Approximately 85 per cent of the radioactive carbon of the labeled citrate that is retained in the rat is converted to $\mathrm{C}^{14} \mathrm{O}_{2}$ in 3 hours. $\Lambda_{\mathrm{p}}$ - proximately 1 per cent of the administered radioactivity was recovered in protein and lipid in the kidneys and liver. The incorporation of $\mathrm{C}^{14}$ into the kidney tissue fractions was greater than that into the corresponding liver fractions.

In vivo and in vitro experiments demonstrated a divergent action of fluoroacetate and fluorocitrate as inhibitors of metabolism. In the intact animal fluoroacetate treatment inhibited the urinary excretion of administered citrate- $\mathrm{C}^{14}$ and enhanced its conversion to respiratory $\mathrm{C}^{14} \mathrm{O}_{2}$; fluorocitrate treatment resulted in an augmentation of the urinary excretion of the citrate- $\mathrm{C}^{14}$ and depressed its conversion to respiratory $\mathrm{C}^{14} \mathrm{O}_{2}$. Studies of the metabolism of liver and kidney slices in the presence of fluoroacetate or fluorocitrate indicated a difference in the mechanism of action of these inhibitors.

Although the distribution of citrate in the subcellular fractions of liver differed from that found in kidney after fluoroinhibitor administration, the localization in each of the tissues was the same, regardless of whether the rat received fluoroacetate or fluorocitrate.

\section{ACKNOWLEDGMENTS}

The skillful technical assistance of Mrs. Marianne Reichlin and Mrs. Gyda Weinstein is gratefully acknowledged.

\section{REFERENCES}

1. Gordon, E. E., and Craigie, A. Effect of intravenous glucose on splanchnic and peripheral metabolism of endogenous pyruvate and citrate in patients with cirrhosis and in subjects without liver disease. J. Lab. clin. Med. 1960, 55, 841.

2. Herndon, R. F., and Freeman, S. Renal citric acid utilization in the dog. Amer. J. Physiol. 1958, 192, 369.

3. Neuman, W. F., Firschein, H., Chen, P. S., Jr., Mulryan, B. J., and Di Stefano, V. On the mechanism of action of parathormone. J. Amer. chem. Soc. 1956, 78, 3863.

4. Mårtensson, J. On the citric acid metabolism in mammals. Acta physiol. scand. 1940, suppl. 2 1, 1.

5. Harrison, H. E. Factors influencing calcium absorption. Fed. Proc. 1959, 18, 1085.

6. Neuman, W. F., and Neuman, M. W. The Chemical Dynamics of Bone Mineral. Chicago, Univ. of Chicago Press, 1958, p. 137.

7. Harrison, H. E. The interrelation of citrate and calcium metabolism. Amer. J. Med. 1956, 20, 1.

8. Gordon, E. E., and Sheps, S. G. Effect of acetazolamide on citrate excretion and formation of renal 
calculi. Report of a case and study of five normal subjects. New Engl. J. Med. 1957, 256, 1215.

9. Peters, R. A. Mechanism of the toxicity of the active constituent of Dichapetalum cymosum and related compounds. Advanc. Enzymol. 1957, 18, 113.

10. Rivett, D. E. A. The synthesis of monofluorocitric acid. J. chem. Soc. 1953 , p. 3710.

11. Aj1, S. J., Wong, D. T. O., and Hersey, D. F. Manometric estimation of citric acid. J. Amer. chem. Soc. 1952, 74, 553.

12. Nordmann, R., Gauchery, O., du Ruisseau, J.-P., Thomas, Y., and Nordmann, J. Chromatographie sur papier des acides organiques non volatils des liquides biologiques. I. L'urine. Technique chromatographique. Bull. Soc. Chim. biol. (Paris) 1954, 36, 1461.

13. Aronoff, J. Techniques of Radiobiochemistry. Ames, Iowa State College Press, 1956, p. 119.

14. Folch, J., Lees, M., and Stanley, G. H. S. A simple method for the isolation and purification of total lipides from animal tissues. J. biol. Chem. 1957, 226, 497.

15. Littlefield, J. W., Keller, E. B., Gross, J., and Zamecnik, P. C. Studies on cytoplasmic ribonucleoprotein particles from the liver of the rat. J. biol. Chem. 1955, 217, 111.

16. Stern, J. R. Assay of tricarboxylic acids in Methods in Enzymology, S. P. Colowick and N. O. Kaplan, Eds. New York, Academic Press, 1957, vol. 3, p. 425 .

17. Schneider, W. C. Methods for the isolation of particulate components of the cell in Manometric Techniques, 3rd ed., W. W. Umbreit, R. H. Burris and J. F. Stauffer, Eds. Minneapolis, Burgess, 1957 , p. 188.
18. Schneider, W. C., Striebich, M. J., and Hogeboom, G. H. Cytochemical studies. VII. Localization of endogenous citrate in rat liver fractions. J. biol. Chem. 1956, 222, 969.

19. Gal, E. M., Peters, R. A., and Wakelin, R. W. Some effects of synthetic fluoro compounds on the metabolism of acetate and citrate. Biochem. J. 1956, 64, 161.

20. Gordon, E. E. Unpublished observations.

21. Novikoff, A. B. Biochemical heterogeneity of the cytoplasmic particles of rat liver. Symp. Soc. exp. Biol. 1957, 10, 92.

22. Gould, R. G., Sinex, F. M., Rosenberg, I. N., Solomon, A. K., and Hastings, A. B. Excretion of radioactive carbon dioxide by rats after administration of isotopic bicarbonate, acetate, and succinate. J. biol. Chem. 1949, 177, 295.

23. Lussier, J. P. Incorporation de l'acide citrique radioactif dans le squelette du rat blanc. Rev. canad. Biol. 1957, 16, 434.

24. Bartlett, G. R., and Barron, E. S. G. The effect of fluoroacetate on enzymes and on tissue metabolism. Its use for the study of the oxidative pathway of pyruvate metabolism. J. biol. Chem. 1947, 170, 67.

25. Kalnitsky, G. The effect of $\mathrm{BaCl}_{2}, \mathrm{MgCl}_{2}$ and fluoroacetate on the formation and utilization of citrate. Arch. Biochem. 1948, 17, 403.

26. Brady, R. O. Fluoroacetyl coenzyme A. J. biol. Chem. 1955, 217, 213.

27. Dickman, S. R., and Speyer, J. F. Factors affecting the activity of mitochondrial and soluble aconitase. J. biol. Chem. 1954, 206, 67.

28. Estermann, E. F., Conn, E. E., and McLaren, A. D. Influence of $\mathrm{pH}$ on particulate and soluble aconitase and glutamic dehydrogenase of Lupinus albus. Arch. Biochem. 1959, 85, 103. 